\title{
Proceeding Paper \\ Effect of Aging with Pollution on the Complex Refractive Index of Pure Submicron Clay Particles ${ }^{\dagger}$
}

\author{
Sarla Yadav ${ }^{1,2}$ and Sumit Kumar Mishra ${ }^{1,2, *}$ \\ 1 CSIR-National Physical Laboratory, New Delhi 110012, India; syysarla@gmail.com \\ 2 Academy of Scientific and Innovative Research (AcSIR), Ghaziabad 201002, India \\ * Correspondence: mishrask@nplindia.org \\ + Presented at the 4th International Electronic Conference on Atmospheric Sciences, 16-31 July 2021; Available \\ online: https:/ / ecas2021.sciforum.net.
}

\begin{abstract}
Modelling the optical and radiative properties of atmospheric particles is governed by one of the key input parameters, i.e., the refractive index of aerosols. Availability of the region-specific refractive index data of aerosols is a major challenge for the atmospheric community. The refractive index of aerosols is a function of their physico-chemical properties. Uncertainty in the computation of the spectral refractive indices of aerosols leads to erroneous assessment of their optical and radiative properties. In the present work, the refractive indices of pure clay (kaolinite, illite) and polluted clay with anthropogenic hematite, $\mathrm{AH}(0.10$ to $1.48 \%)$ submicron particles have been computed for the wavelength range of 0.38 to $1.2 \mu \mathrm{m}$. Anthropogenic hematite enhanced the overall absorption in the $\mathrm{UV}$ and visible range with maximum absorption at lower wavelengths (less than $0.55 \mu \mathrm{m}$ ).
\end{abstract}

Keywords: complex refractive index; submicron pure clay; kaolinite; illite; polluted clay

\section{check for} updates

Citation: Yadav, S.; Mishra, S.K. Effect of Aging with Pollution on the Complex Refractive Index of Pure Submicron Clay Particles. Environ. Sci. Proc. 2021, 8, 31. https:// doi.org/10.3390/ecas2021-10327

Academic Editor: Anthony R. Lupo

Published: 22 June 2021

Publisher's Note: MDPI stays neutral with regard to jurisdictional claims in published maps and institutional affiliations.

Copyright: (c) 2021 by the authors. Licensee MDPI, Basel, Switzerland. This article is an open access article distributed under the terms and conditions of the Creative Commons Attribution (CC BY) license (https:/ / creativecommons.org/licenses/by/ $4.0 /)$.

\section{Introduction}

Fine clay particles are natural aerosols present in the atmosphere. Submicron clay particles interact with anthropogenic species during long-range transport, which alters the optical and radiative behavior of particles. The physico-chemical (morphology and composition) properties of an aerosol govern its absorption and scattering behavior [1-4]. The spectral refractive index is an important parameter in governing the optical properties of aerosols $[2,5,6]$. The refractive index is composed of real and imaginary parts. The real part of the refractive index is responsible for the scattering behaviour of the aerosol, while its absorbing nature is determined by the imaginary part $[7,8]$.

For the assessment of optical and radiative properties of aerosols, it is necessary to understand the complex refractive index of aerosols. In the present work, the effect on the spectral refractive index of pure clay aged with pollution species has been studied.

\section{Methodology}

The $\mathrm{PM}_{2.5}$ aerosol samples were collected in Delhi at CSIR-NPL $\left(28.70^{\circ} \mathrm{N}, 77.10^{\circ} \mathrm{E}\right)$ using an Envirotech sampler (model: APM 550). Elemental analysis revealed occurrence of aluminosilicates (kaolinite (K) and illite (I)), which is evidenced by earlier studies $[9,10]$. Based on the aforesaid findings, the mixture of $(20 \% \mathrm{~K}+80 \% \mathrm{I})$ of pure clay is considered for the study. Pure clay mixture was then aged with pollution with varying anthropogenic hematite $(\mathrm{AH})(0.10 \%$ to $1.48 \%)$. Effective refractive index was calculated using the volume mixing rule.

\section{Result and Discussion}

Studies show that the anthropogenic iron emitted from various sources ranges from $0.10 \%$ to $1.48 \%$. Figure 1 shows the spectral refractive index of pure submicron clay mixture aged with $\mathrm{AH}$ for aforementioned $\mathrm{AH}$ percentages, i.e., $0.10 \%$ and $1.48 \%$. Aging with $\mathrm{AH}$ 
increased the overall $\mathrm{k}$ value of the refractive index in UV, visible and NIR wavelengths. The maximum enhancement was observed at $0.38 \mu \mathrm{m}$ wavelength. Hematite acts as strong absorber of incoming solar radiation, especially at short wavelengths in the blue spectral region [1,11-13]. Maximum enhancement in the k value was observed below the wavelength of $0.55 \mu \mathrm{m}$.

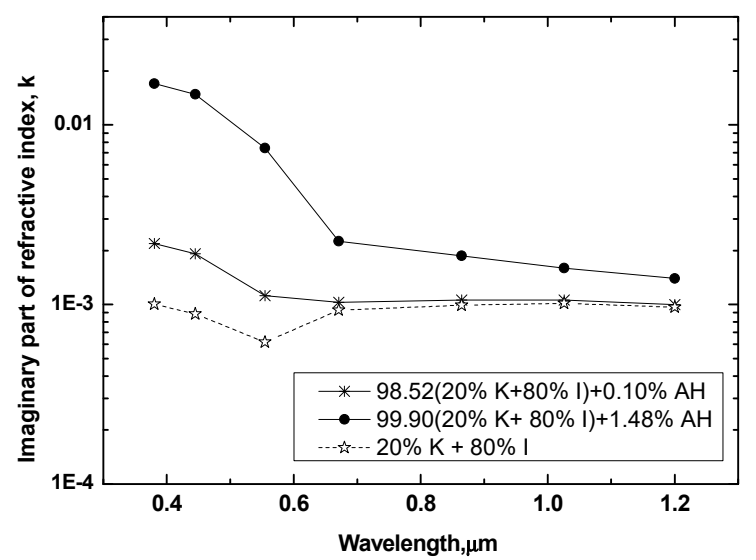

Figure 1. Imaginary part of the refractive index, k of submicron clay particles $(20 \%$ Kaolinte $+80 \%$ Illite mixture) which are polluted with varying percentage of anthropogenic hematite $0.10 \%$ and $1.48 \%$. Where $\mathrm{K}=$ Kaolinite; $\mathrm{I}=$ Illite; $\mathrm{AH}=$ Anthropogenic Hematite.

\section{Conclusions}

The complex refractive index of pure submicron clay particles is influenced by the aging with the considered species. Anthropogenic species such as AH enhance the absorption due to their absorbing behaviour.

Conflicts of Interest: The authors declare no conflict of interest.

\section{References}

1. Mishra, S.K.; Tripathi, S.N. Modeling optical properties of mineral dust over the Indian Desert. J. Geophys. Res. Space Phys. 2008, 113. [CrossRef]

2. Mishra, S.K.; Agnihotri, R.; Yadav, P.; Singh, S.; Prasad, M.V.S.N.; Praveen, P.S.; Tawale, J.S.; Rashmi; Mishra, N.D.; Arya, B.C.; Sharma, C. Morphology of atmospheric particles over semi-arid region (Japur, Rajasthan) of India: Implication for optical properties. Aerosol Air Qual. Res. 2015, 15, 974-984. [CrossRef]

3. Mishra, S.K.; Saha, N.; Singh, S.; Sharma, C.; Prasad, M.V.S.N.; Gautam, S.; Misra, A.; Gaur, A.; Bhattu, D.; Ghosh, S.; et al. Morphology, Mineralogy and Mixing of Individual Atmospheric Particles Over Kanpur (IGP): Relevance of Homogeneous Equivalent Sphere Approximation in Radiative Models. MAPAN 2017, 32, 229-241. [CrossRef]

4. Mishra, S.; Ahlawat, A.; Khosla, D.; Sharma, C.; Prasad, M.; Singh, S.; Gupta, B.; Tulsi; Sethi, D.; Sinha, P.; et al. Experimental investigation of variations in morphology, composition and mixing-state of boundary layer aerosol: A balloon based study over urban environment (New Delhi). Atmos. Environ. 2018, 185, 243-252. [CrossRef]

5. Cappa, C.D.; Che, D.L.; Kessler, S.H.; Kroll, J.H.; Wilson, K.R. Variations in organic aerosol optical and hygroscopic properties upon heterogeneous OH oxidation. J. Geophys. Res. Space Phys. 2011, 116. [CrossRef]

6. Goel, V.; Mishra, S.K.; Lodhi, N.; Singh, S.; Ahlawat, A.; Gupta, B.; Das, R.M.; Kotnala, R. Physico-chemical characterization of individual Antarctic particles: Implications to aerosol optics. Atmos. Environ. 2018, 192, 173-181. [CrossRef]

7. Bohren, C.F.; Huffman, D.R. Absorption and Scattering of Light by Small Particles; WILEY-VCH Verlag GmbH \& Co. KGaA: Weinheim, Germany, 1998. [CrossRef]

8. Seinfeld, J.H.; Pandis, S.N.; Noone, K. Atmospheric Chemistry and Physics: From Air Pollution to Climate Change. Phys. Today 1998, 51, 88-90. [CrossRef]

9. Soil Survey and Land Use Plan of Delhi Territory; National Bureau of Soil Survey and Land Use Planning: Maharashtra, India, 1979.

10. Tomar, K.P. High-spacing irregularly interstratified layer-silicates in the alluvial soil clays of Meerut, India. Clay Miner. 1985, 20, 115-124. [CrossRef]

11. Zhang, X.L.; Wu, G.J.; Xu, T.L.; Zhou, Q.Q. What is the real role of iron oxides in the optical properties of dust aerosols? Atmos. Chem. Phys. Discuss. 2015, 15, 12159-12177. [CrossRef] 
12. Longtin, D.R.; Shettle, E.P.; Hummel, J.R.; Pryce, J.D. A Wind Dependent Desert Aerosol Model: Radiative Properties; AFGL-TR-88-0112; Air Force Geophysics Laboratory: Hanscom AFB, MA, USA, 1988; p. 115.

13. Derimian, Y.; Karnieli, A.; Kaufman, Y.J.; Andreae, M.O.; Andreae, T.W.; Dubovik, O.; Maenhaut, W.; Koren, I. The role of iron and black carbon in aerosol light absorption. Atmos. Chem. Phys. Discuss. 2008, 8, 3623-3637. [CrossRef] 